\title{
A Review of the Use of Information Technology in Brazilian Schools from 2010 to 2014
}

\author{
Eurival Alves de Souza, Leandro Guimarães Garcia, Janio Carlos Nascimento Silva, Leonardo \\ Guimarães Garcia, and Patrick Letouze Moreira
}

\begin{abstract}
The paper discusses the presence of Information and Communication Technology (ICT) in Brazilian schools, based on documents of the last five years obtained from two sources: the Brazilian Internet Steering Committee (CGI.br) database that stores surveys on the use of information and communication technologies in Brazilian schools; the Scientific Electronic Library Online (SciELO) database - a prominent Portuguese and Spanish repository of scientific journals. The CGI.br surveys indicate slow improvements (mainly related to the growing number of mobile ICT in schools) but important limitations (low speed of Internet at schools, low investment in teachers training, low equipment number, etc.). Even under these conditions, it outlines the trend of using ICT mobile devices that shifts the ICT usage from computer labs to the classroom. The latest scientific studies on ICT retrieved from SciELO corroborate this perception, based on an analysis of all ICT and virtual tools considered by researchers, as well as the context in which the studies were performed (including the research and teaching methods, and type of courses considered).
\end{abstract}

Index Terms-Information, communication technologies, school, e-learning, Brazil.

\section{INTRODUCTION}

In one century, the world has changed dramatically in terms of education. At the beginning of the 20th century, the world lived in the 'industrial society', where schools were isolated of the real people interests, teachers didn't stimulate abilities such as communication, and students had passive behavior in the classroom. Nowadays, schools are integrated with society, knowledge is widely available, teachers stimulate communication and students have become more active in the teaching-learning process [1].

Nowadays, this change is supported by cultural and technological elements of the current 'information era', in which Information and Communication Technologies (ICT) has a substantial role [2]. Consequently, the impacts of ICT in education, especially in the teaching and learning process have become an interesting topic for many researchers [3].

ICT provides a wide range of possibilities on the

Manuscript received June 26, 2015; revised January 21, 2016. This work was partly supported by CNPq and UFT through scholarships to some of the students who helped in this work.

E. A. de Souza and J. C. N. Silva are with Federal University of Tocantins, Tocantins, Brazil.

L. G. Garcia is with the Faculty of Medicine, Federal University of Tocantins, Brazil (e-mail: lggarcia@uft.edu.br).

L. G. Garcia is with the Faculty of Education, Information and Comunication, University of Sao Paulo, Brazil.

P. L. Moreira is with the Graduate Program of Systems' Computational Modeling, Federal University of Tocantins, Brazil. generation of learning environments to promote the access to a massive amount of information, which can be visualized in different ways [4]. In seconds, a subject can be sorted by videos, texts, blogs and social network posts. ICT also offers a unique platform, for example a smartphone and elements such as books, telephone, TV, maps, games, etc. [5].

The advantages of the ICT in classrooms are amplified by the understanding that instruments such as computers make learning easier and playful [6]. The computer, moreover, appears in the literature as a central tool in the application of ICT in school environments [7]-[9].

The use of computer and other technologies helped to build the concept of e-learning (electronic learning). In [10] we get the following definition about e-learning:

"e-Learning includes instruction delivered via all electronic media including the Internet, intranets, extranets, satellite broadcasts, audio/videotape, interactive TV, and CD-ROM. All efforts to implement e-Learning will eventually move towards total automation of administrating the teaching and learning processes by means of a software known as Learning Management Systems (LMS)."

From the definition presented in [10], we realize that the presence of ICT in education goes beyond the use of computers and the internet, and that e-learning may be used to regular education as well as to online learning courses.

The amplitude of the usage of new technologies on education may be seen by different points of view. The work of [11] develops an integrated model to evaluation of critical factors of success and satisfaction of the students on the use of e-learning in online learning courses. This integrated model is composed by six dimensions: Learner Dimension, Instructor Dimension, Course Dimension, Technology Dimension, Design Dimension e Environmental Dimension. To list these dimensions, [11] used eight works published between 2000 and 2003 that approach critical factors of success that affect the satisfaction of students on e-learning systems.

The learner dimension is connected to the learner's attitude in relation to the ICT (considering aspects as the learner's acceptance and his self-efficacy on the usage of these tools). The instructor dimension is associated to the instructor's attitude in relation to the appropriate use of ICT in a school (for example, quick answer to questions posted by the learners in a forum). The course dimension is related to the quality and flexibility offered by the course that uses ICT. The technology dimension is related to the quality of the technology in use (like, for example, the quality of the internet or of the computers used). The design dimension is related to the learners' and instructors' perception about the importance of the use of ICT, and it also considers the ease of use of the ICT 
adopted. Finally, the environmental dimension is associated to many factors like diversity in assessment and learner perceived interaction with others.

Although the wideness of our research, which is not only dedicated to the evaluation of online courses, we believe that the notions described above represent an important guide to the appropriate analysis of the studies evaluated on this article. Consequently, in this work we will use the notion of six dimensions allied to the appropriate use of ICT to critically analyze the evaluated studies.

Despite the advantageous scenario of ICT in schools, and even the example of governmental support for its implementation in many countries [12], the use of these tools in school still faces problems. Primary and secondary school teachers have great difficulty adapting their traditional teaching strategies to the new technological reality. Bingimlas in [13], has highlighted five main difficulties: i) Lack of access to good hardware and software infrastructure in schools; ii) resistance to change to traditional teaching methods; iii) lack of time (mostly because of work overload); iv) lack of appropriate training; and v) lack of technical support at schools.

In this work, we analyze the current situation of ICT in Brazilian schools. Our goal is to establish a global vision of the schools situation in face of the possibilities of ICT usage discussed by researchers.

Due to the variety of technical terms used in the related scientific literature, we have decided to use words as teacher and instructor indistinctly, as well as e-learning and ICT in education, and student and learner. We believe that in this specific context to assume such synonymy will not induce any conceptual misunderstanding.

\section{Methodology}

The article discusses the presence of ICT in Brazilian schools based on documents of the last five years obtained from two sources: a) the Brazilian Internet Steering Committee (CGI.br) database; b) the Scientific Electronic Library Online (SciELO) database.

CGI.br is a multilateral committee that congregates government and civil society to establish strategic directives related to the use and development of the Internet in Brazil, promote studies and recommend procedures for Internet security, and propose research and development programs to maintain the level of technical quality and innovation in the use of Internet [14].

Once a year, the cgi.br unit called "Brazilian Network Information Center" (NIC.br) publishes in their database a survey on the use of ICT in Brazilian schools. These studies are conducted in public and private schools located in Brazilian urban areas, excluding schools maintained by the Federal Government.

The group of students surveyed belongs to one of the following three series: the fifth year (the middle point of Brazilian elementary school), the ninth year (the final year of elementary school) and eleventh year (the middle point of high school). Also all principals, coordinators and teachers involved in the surveyed groups were inserted in the sample.
In this study, we used the last four survey reports (2010 to 2013) to understand the general situation of ICT in schools.

SciELO is a "model for cooperative electronic publishing of scientific journals on the Internet, especially conceived to meet the scientific communication needs of developing countries" [15]. This open access database of scientific journals, available at http://www.scielo.org, has 1255 journals covering 38379 issues, including education. Considering the prominence of this repository in Brazil and the objective of analyzing possibilities of ICT in Brazilian schools through academic research, we evaluate that SciELO should be a good choice.

In SciELO, we retrieved papers published from 2010 to 2014 related to the use of ICT in Brazilian schools. The data was collected by electronic search, using combinations of the following keywords: cell phone, computer, data show, education, teaching, internet, laptop, digital board, notebook, tablet and technologies. This search in titles and abstracts resulted in 253 primary studies.

Some filters were used to select from the papers retrieved those really relevant to our goals. We consider works focusing on schools, written in Portuguese and performed in Brazil, where ICT were used to teach or to train teachers or students. On the other hand, articles merely theoretical, with no practical approach to schools, out of the range and repeated were excluded. After this procedure, there remained 46 studies.

Finally, after thoroughly reading the 46 selected studies, only 28 actually fit to this study (Table I). Of these papers, 18 evaluated ICT use in theoretical and practical teaching, or training of teachers and students and 10 reviews of the usage of ICT in schools.

TABLE I: STUDIES OBTAINED IN EACH STEP OF THE BIBLIOGRAPHIC REVIEW

\begin{tabular}{llll}
\hline \hline Database & Identified studies & Selected studies & Included studies \\
\hline GGI.br & 4 studies & 4 studies & 4 studies \\
SciELO & 253 articles & 46 articles & 28 articles \\
\hline \hline
\end{tabular}

\section{ChARACTERIZATION OF ICT IN BRAZILIAN SCHOOLS BASED ON CGI.BR STUDIES}

The studies performed by CGI.br present a lot of different indicators and perspectives on ICT. Following the purpose of this study, we prioritized four dimensions to discuss: 1) ICT infrastructure in public schools; 2) Internet access in public schools; 3) Teachers training; 4) Use of technology by the students.

\section{A. ICT Infrastructure in Public Schools}

Computer desktops are the most common ICT in Brazilian public schools, although in small number considering the average per student. In 2013, 99\% of Brazilian public schools in urban areas were equipped with desktop computers for pedagogical purposes, on an average of 1 computer to 39 students (most installed in computer labs). A study of 2009 covering 400 Brazilian public schools in different state capitals [16] revealed the high presence of TVs (99\%), DVD players $(98 \%)$, data projector $(85 \%)$, digital camera $(79 \%)$ and video camera $(50 \%)$, but in small amount. 
Despite the dominance of desktops, there is a mobility trend supporting the ICT dislocation from labs to classroom. In 2013, $73 \%$ of Brazilian public schools have at least one portable computer and in $11 \%$ at least one tablet. Although modest in absolute value, these percentages are much larger than found in 2010. Moreover, $47 \%$ of teachers use their portable computers to minimize the infrastructure problems, normally to support pedagogical activities with students and to prepare the classes.

In summary, data points limitation on ICT Brazilian public schools infrastructure. However, it shows a mobility trend with the increase of mobile devices in schools and classrooms.

\section{B. Internet Access in Public Schools}

In 2013, 95\% of Brazilian public schools had internet access, $55 \%$ with a maximum connection speed of 2 mbps (megabits per second) to the whole school, and only $19 \%$ with connection speed of $3 \mathrm{mbps}$ or more. This is one of the most important indicators of technological limitation of Brazilian public schools.

Despite the low internet connection speed, from 2010 to 2013 the CGI.br studies show a growth of its use in classrooms, as well as a reduction in computer labs. It corroborates the mobility trend existence for ICT and the centrality of classroom instead of computer labs.

\section{Teachers Training}

Even though the understanding that institutional support for ICT teacher training is essential to the implementation of technologies and its continuous and effective use [17], in 2013 only $35 \%$ of public schools offer their teachers any kind of training on this, while $86 \%$ of pedagogical coordinators consider the increase of teachers technical abilities a priority action. It explains why almost $75 \%$ of the teachers interviewed complained about the lack of pedagogical support on ICT from the schools.

In spite of low incomes and the consequently overload of Brazilian teachers, nearly $53 \%$ of them claim to have done some specific course to learn how to use computers and internet as a teaching-learning process tool. Within this group, $78 \%$ claimed that this course was paid by themselves.

The 2013 study shows that $83 \%$ of the teachers with any contact with ICT as a pedagogical tool during their undergraduation and consider this fact contributed to the use of these tools with their students. Considering that the use of ICT as a support tool for the learning process is more and more common in college courses, it becomes an important route to indirect ICT training for young teachers.

Teachers also said they learned how to use these technologies by themselves, with people of their social circle, with other teachers and students. When the learning occurs by themselves or with the help of people from their social circle, they tend to use these tools in classrooms. On the other hand, teachers that had learned how to use these technologies from other teachers tended to use them in the computer lab.

\section{Use of Technologies by Students}

In 2013, about 50\% of the students declared themselves concerned about comparing different sites to know if the obtained information is true. Beyond that, $31 \%$ of the students told that they do not have any difficulty on using spreadsheets. On the other hand, most of the students alleged to be able to perform, without any problem, tasks that require the use of text editors, programs for visualization of multimedia content, or even filing of any document in a folder.

In 2013, 69\% of students had a desktop computer at home, and $51 \%$ a portable computer (compared to $18 \%$ in 2010), supporting the mobility ICT trend. The internet access also rose, from $44 \%$ in 2010 to $65 \%$ in 2013.

The access of internet through smartphones became an important issue, responsible for $39 \%$ of internet access inside the schools, mainly for research, message exchanges, emails and social networking websites.

The fact that $87 \%$ of the students claimed that they use internet to do school homework indicates advances. However, the use of ICT in its whole potential depends on the contribution of schools and teachers and, as discussed earlier in this section, there are important limits related to infrastructure and training.

On the other hand, the mobility trend can be seen as an opportunity to overcome this situation. With the dislocation of ICT to the classroom, teachers and students could perform collective and participative activities involving their own mobile devices and those that are purchased by schools.

The natural interest of students with ICT opens possibilities of using virtual tools and educational platforms for semipresential or distance learning with the spirit of learning-by-doing. This motivation could compensate part of the limitations and generate good results.

In this technological and educational changing context, the opportunities cited above request a partnership between research and education. To know the latest educational ICT solutions studied by researchers, we analyzed the papers retrieved from SciELO published from 2010 to 2014. The main results are compiled in the next section.

\section{REVIEW ABOUT ICT IN BRAZILIAN SCHOOLS BASED ON SCIELO}

Analyzing the 28 articles obtained from SciELO, it was observed that 10 were reviews and 18 were new researches. Since the purpose of these works is different, each group was discussed separately.

\section{A. Reviews about ICT Usage in Schools}

The first step was analyzing the 10 reviews retrieved from SciELO. Thus, we would have a better understanding of the other 18 articles. The items below present the main challenges and advantages for ICT in Brazilian schools according to the retrieved reviews:

Ref. [18] brings to light the importance of teachers training for an appropriate use of ICT in classrooms. More than this, it states that it is not enough just introduce the tools to teachers, or teach them how to use the technologies. To the author, teachers must experience fully the cyberculture and the potentialities of digital networks, preparing themselves to create their customized solutions.

Ref. [19] analyzes 9650 posts of elementary school teachers obtained from a collaborative pedagogical environment called "Dia-a-dia Educação," in which: 1) the 
production, publication and validation of pedagogical contents are exclusively mediated by ICT; 2) all the publications are produced at a distance; and 3) the content published can be complemented by any authenticated user. This study criticized the state intervention, which established control of content available and limiting personal and professional relationships among the teachers.

Ref. [20] discusses ICT as pedagogical tools and their implications over education. It also debates the appropriate use of internet, and defends that virtual learning overrides traditional methods. The author points to the need of every teacher to become an author and researcher in this technological world.

Ref. [21] debates the role of teachers in information and knowledge society. Teachers should learn how to apply critically the many ways of expression allowed by multimedia in order to educate conscious individuals.

Ref. [22] discusses some myths around the use of ICT in education, like the opposition between the thinking process and the process of using digital technologies, or the ICT access can democratize the access to knowledge, making possible a state of social justice and generalized prosperity.

Ref. [23] presents important aspects of the Brazilian National Education Plan related to ICT. According to the author, the power of the technological tools is so large that they assimilate a kind of modus vivendi, which gives them the condition of subjects, while human beings are gradually relegated to the condition of objects. Another belief that demands critical thought is that a well-structured LMS (learning management systems) could totally replace the pedagogical role of the teachers, limiting them to a secondary role in the teaching and learning process.

Ref. [24] analyzes different issues associated to the use of ICT in education, for example the "fetishization" of ITCs, the multimedia configuration of information, the possibility of teachers replacement by the ICT, the meaning of ICT to directors, teachers and students of different social classes, the need for new concepts of learning and teaching in the "knowledge society," and how to prepare teachers to dominate critically the use of these tools.

Ref. [25] discusses the role of teachers in the "knowledge society," where their image can be violated and their instructions can be questioned by students. The work exposes the fact that the information quickly accessed by the internet, which is frequently fragmented, generating distraction.

Ref. [26] is a review based on 107 scientific works about the use of computers in Brazilian schools, from 1997 to 2007. This study divides schools in two groups: 1) schools which believe that computers can solve problems related to teaching and learning questions; 2) schools which deny this possibility. Inside the first group, there are two approaches for ICT: a) the instrumental approach, in which ICT are pedagogical-didactical sources modeled by individuals; and b) the technological determinism, in which technology represents a new paradigm that should be imposed in schools as a condition for a modern education.

Ref. [27] makes a systematic review based on 46 scientific studies published from 1997 to 2011. This article shows that the use of computers and internet increased at the end of the 1990s. It also highlights a large number of scientific papers about e-learning and criticizes the simplistic and instrumental way the computer and internet are used.

Those 10 reviews, representing hundreds of papers, establish the big picture from which we could interpret the current research. Based on these understandings, we summarized the 18 studies ([28]-[45]) to propose a landscape from the latest research about ICT in Brazilian schools.

\section{B. ICT, Tools and Methods Tested by Researchers}

Figure 1 shows the ICT analyzed by researchers in their papers. As discussed earlier, computers and internet are essential, but new mobile devices (smartphone and tablet) appear as a new trend, becoming relevant research objects, especially when we consider the fact that the number of smartphones is currently bigger than the number of computers in Brazil [46]. Another important data is that nearly one third of all Brazilian population uses the internet through smartphones [47].

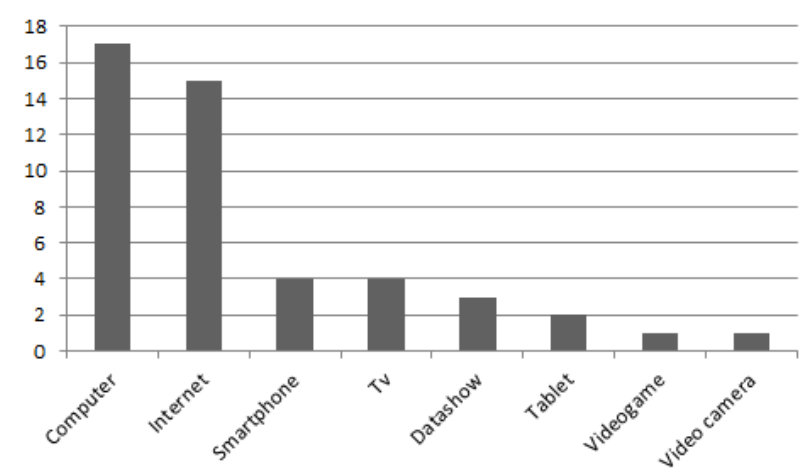

Fig. 1. ICT occurrence in the selected papers.

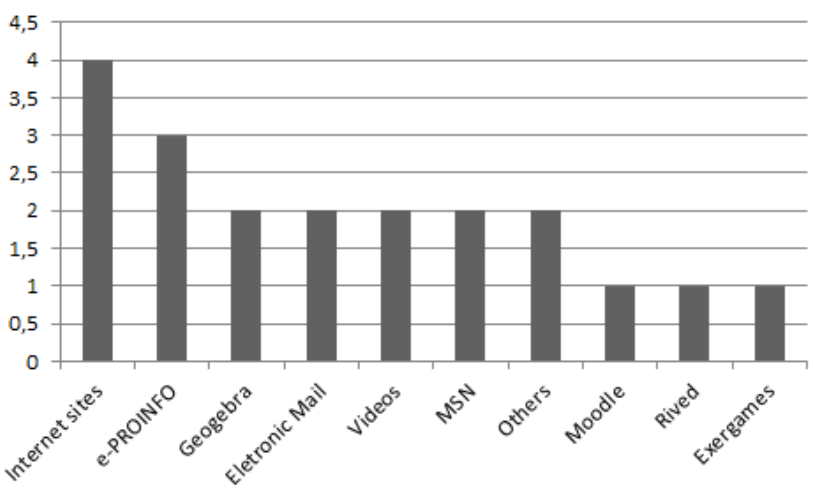

Fig. 2. Virtual tools used in the selected papers

Fig. 2 shows virtual tools that, combined with the hardware of Fig. 1, allow the construction of real educational solutions. It's absolutely clear the dominance of internet-based tools, from the sites to the services (electronic mail, MSN, video repository) and virtual platforms (Moodle, Rived and e-PROINFO) run from the network, which is positive for the mobility trend.

In a few words, Rived is an interactive virtual education network created by Federal Governments of several Latin American countries to allow students and teachers to access educational multimedia content. e-PROINFO is a collaborative virtual learning environment created by the Brazilian Federal Government that enables the design, management and development of distance learning courses. Geogebra is a software for teaching geometry.

Fig. 3 shows the courses modality. We verified the 
existence of distance and semipresential courses, as well as regular classroom courses. The dominance of research about presential courses shows that the main worry is to understand the impact and the possibilities of ICT on traditional solutions, including the dislocation of ICT to classrooms.

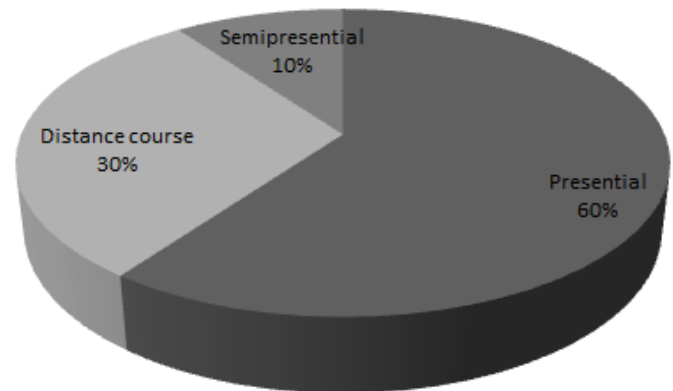

Fig. 3. Occurrence of course modality in the selected papers.

Fig. 4 shows the teaching methods used. The important presence of active learning methodologies, based on projects and problems, indicates an association between this and ICT use. Additional studies are needed to understand the causes, but this evidence suggests the need for innovative teachers, able to integrate teaching and research. Thus, it becomes more evident the importance of teachers training for an effective use of ICT.

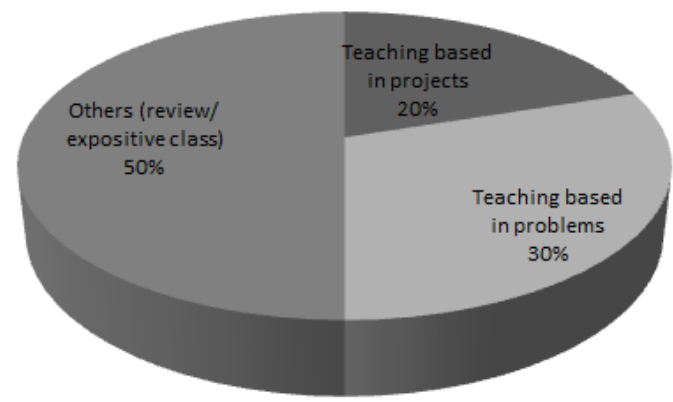

Fig. 4. Teaching methods in the selected papers.

Fig. 5 presents the research methods used in studies. The low presence of experimental studies and action research indicates that only a small portion of the studies were conducted by direct intervention of the evaluator during the research. This information can be explained by the fact that many researchers are only ICT users, presenting little or any ability to produce or modify contents in this context. We believe that may happen a change in the frequency observed to the research methods of ICT in Brazil along the next years with the substitution of the current generation of researchers to a new generation with more intimacy to the ICT since a very young age in daily life.

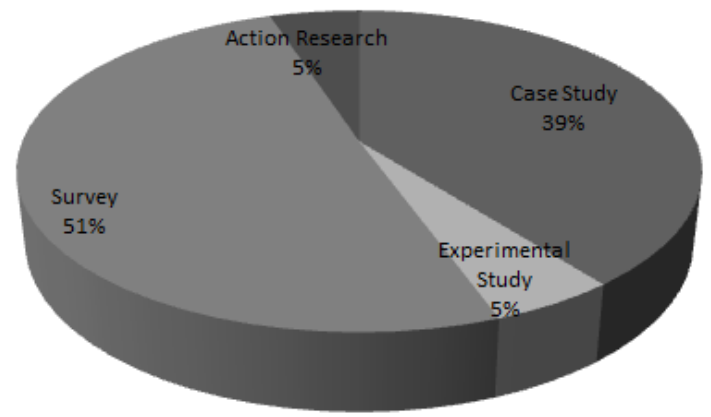

Fig. 5. Occurrence of adopted research methods.

\section{CONCLUSION}

This article presents a review based on different sources of information, about the situation of ICT usage in Brazilian schools in the past five years.

The approach for this construction involved the establishment of an overview of ICT in Brazilian education (basically composed by reviews obtained from SciELO database), followed by the description of key variables of ICT usage in schools (ICT infrastructure in schools, internet in schools, teachers training and the use of technology by students). With this knowledge, it was possible to develop an analytical approach for the latest scientific studies on ICT in Brazilian schools, and to compare the results with the perceptions established in the previous activities.

At first, we realized that an overwhelming part of the evaluated studies focus only on learner, instructor and technology dimensions. The design dimension, when mentioned, was more directed to the instructor's perception about the importance of the use of ICT in classroom. Course and environmental dimensions were practically ignored in the studies evaluated.

Within the dimensions evaluated, our research revealed slow improvements (mainly related to the growing number of mobile devices in schools) but important limitations (low speed of Internet at schools, low investment in teachers training, low equipment number, etc.). Even under these conditions, the usage of mobile devices tends to shift the ICT educational process from computer labs to the classroom.

The latest scientific studies on ICT retrieved from SciELO corroborate this perception, as shown by the discussions of section IV.B based on an analysis of all ICT and virtual tools considered by researchers, as well as the context in which the studies were performed (including the research and teaching methods and type of courses considered).

Thus, our approach for understanding the ICT presence in Brazilian schools provided suggestions to expand the use of ICT in this context. However, the complexity and changeability of our "information and knowledge society" require more than establish assertive actions in the present. So, this work reinforces the need to develop competences for the continuous understanding of ICT and their incorporation in education, respecting critical thinking, ethics and the projects of students, teachers and the school itself.

We conclude this work with this important reflection to keep in mind [48]:

"Incorporating ICT into the educational policies of Latin American countries has been linked to purposes of coverage expansion and teaching quality improvement. The relationship between their use and the quality of education is a controversial topic, but although it is true that ICT alone - or their best use - cannot solve important problems in education, it is even more difficult to aspire to quality education in a connected society when these technologies are not present."

\section{REFERENCES}

[1] W. J. Pelgrum, A. C. A. T. Brummelhuis, B. A. Collis, T. Plomp, and I. A. M. J. Reinen, "The application of multimedia technologies in schools: technology assessment of multimedia systems for pre-primary and primary schools," Luxembourg: European Parliament, Directorate General for Research, 1997. 
[2] M. Volman, E. Eck, I. Heemskerk, and E. Kuiper, "New technologies, new differences. Gender and ethnic differences in pupils' use of ICT in primary and secondary education," Computers \& Education, vol. 45 , no. 1, pp. 35-55, August 2005.

[3] E. Ramírez, J. Martín-Domínguez, B. Orgaz, and I. Cañedo, "Analysis of classroom practices with an ICT resource in early childhood education," Computers \& Education, vol. 86, pp. 43-54, August 2015

[4] E. Smeets, "Does ICT contribute to powerful learning environments in primary education?" Computers \& Education, vol. 44, no. 3, pp. 343-355, April 2005

[5] S. Livingstone, "Critical reflections on the benefits of ICT in education," Oxford Review of Education, vol. 38, no. 1, pp. 9-24, February 2012.

[6] I. L. Parellada, and S. É. Rufini, "O uso do computador como estratégia educacional: Relações com a motivação e aprendizado de alunos do ensino fundamental," Psicologia: Reflexão e Critica, vol. 26, no. 4, pp 743-751, December 2013.

[7] J. Akker, P. Keursten, and T. Plomp, "The integration of computer use in education," International Journal of Educational Research, vol. 17, no. 1, pp. 65-76, 1992.

[8] J. A. Valente, "Por que o computador na educação?" Computadores e Conhecimento: Repensando a Educação, Campinas: Unicamp/Nied, pp. 24-44, 1993.

[9] J. M. Roschelle, R. D. Pea, C. M. Hoadley, D. N. Gordin, and B. M. Means, "Changing how and what children learn in school with computer-based technologies," The Future of Children, vol. 10, no. 2, pp. 76-101, 2000.

[10] T. Govindasamy, "Successful implementation of e-learning Pedagogical considerations," The Internet and Higher Education, vol. 4, no. 3-4, pp. 287-299, 2001.

[11] P. C. Sun, R. J. Tsai, G. Finger, Y. Y. Chen, and D. Yeh, "What drives a successful e-learning? An empirical investigation of the critical factors influencing learner satisfaction," Computers \& education, vol. 50, no. 4, pp. 1183-1202, May 2008.

[12] W. J. Pelgrum, "Obstacles to the integration of ICT in education: results from a worldwide educational assessment," Computers \& Education, vol. 37, no. 2, pp. 163-178, September 2001.

[13] K. A. Bingimlas, "Barriers to the successful integration of ICT in teaching and learning environments: A review of the literature," Eurasia Journal of Mathematics, Science \& Technology Education, vol. 5, no. 3, pp. 235-245, August 2009.

[14] The Brazilian Internet Steering Committee (CGI.br) CGI.br-Publications. [Online]. Available: http://www.cgi.br/publicacoes/indice/pesquisas/

[15] The Scientific Electronic Library Online (SciELO). SciELO Homepage. [Online]. Available: http://www.scielo.org/php/index.php

[16] R. D. Lopes, I. K. Ficheman, A. A. G. Martinazzo, A. G. D. Correa, V. Venâncio, H. T. Yin, and L. C. Biazon, "O uso de computadores e da internet nas escolas públicas de capitais brasileiras," Estudos \& Pesquisas Educacionais, vol. 1, pp. 275-336, 2010.

[17] N. Davis, C. Preston, and I. Sahin, "Training teachers to use new technologies impacts multiple ecologies: Evidence from a national initiative," British Journal of Educational Technology, vol. 40, no. 5 , pp. 861-878, September 2009.

[18] N. D. L. Pretto and N. C. R. Riccio, "College professors continuing education and digital technologies," Educar em Revista, no. 37, pp. 153-169, May 2010.

[19] G. G. D. Menezes, "ICT use in teacher training proceedings and the teachers' participation in practice communities," Educar em Revista, no. 51, pp. 283-299, January 2014.

[20] A. M. Karwoski and J. C. O Bernardo, "DEMO, pedro. educação hoje: 'Novas' tecnologias, pressões e oportunidades," Educação em Revista, vol. 27, no. 2, pp. 325-332, August 2011.

[21] A. P. D. Baladeli, M. S. F. Barros, and A. Altoé, "Challenges for teachers in the information society," Educar em Revista, no. 45, pp. 155-165, July 2012.

[22] R. M. B. Fischer, "Some mythologies about new technologies and education," Educação \& Sociedade, vol. 33, no. 121, pp. 1037-1052, October 2012.

[23] A. A. Zuin, "The national plan for education and the information and communication technologies," Educação \& Sociedade, vol. 31, no. 112 , pp. 961-980, July 2010

[24] I. Schapper, "Por entre discursos, tecnologias e educação," Educação \& Sociedade, vol. 31, no. 110, pp. 287-289, January 2010.

[25] V. G. Zuin and A. Á. S. Zuin, "Teachers, digital technologies and concentrated distraction," Educar em Revista, no. 42, pp. 213-228, October 2011.
[26] J. Peixoto and C. H. S. Araújo, "Tecnologia e educação: algumas considerações sobre o discurso pedagógico contemporâneo" Educação \& Sociedade, vol. 33, no. 118, pp. 253-268, January 2012.

[27] T. M. Bach, M. J. C. de S. Domingues, and S. A. Walter, "Tecnologias da informação e comunicação no ensino: um estudo bibliométrico e sociométrico de 1997-2011," Avaliação: Revista da Avaliação da Educação Superior, vol. 18, no. 2, pp. 393-416, July 2013.

[28] C. A. A. P. Abar and S. V. Alencar, "The instrumental genesis and its interaction with GeoGebra: A proposal for continuing education for mathematics teachers," Bolema: Boletim de Educação Matemática, vol. 27, no. 46, pp. 349-365, August 2013.

[29] J. L. A. F. Garcez, F. R. Maciel, and V. M. B. Cardoso, "Considerações ergonômicas para aplicação de mídia em ambientes educacionais para crianças do ensino fundamental," Produção, vol. 22, no. 2, pp.284-295, March 2012

[30] G. L. Santos, "Distance education in the continuing professional training of basic education teachers: Analyzing didactic agreement and disagreements from a case study," Educar em Revista, no. 52, pp. 275-290, April 2014

[31] F. D. S. S. Miranda, "Integration of digital information technologies and communication in learning contexts: Analysis of three different moments of a teacher development course," Trabalhos em Linguística Aplicada, vol. 53, no. 1, pp. 55-77, January 2014

[32] A. B. D. Siqueira and M. P. Cerigatto, "Media-education for High School: why and how to do it," Educar em Revista, no. 44, pp. 235-254, April 2012.

[33] A. A. Machado, M. Callegari, and A. Moioli, "Body human development and technologies," Motriz: Revista de Educação Física, vol. 17, no. 4, pp. 728-737, October 2011.

[34] A. F. D. O. Baracho, F. J.Gripp, and M. R. D. Lima, "Os exergames e a educação física escolar na cultura digital," Rev. Bras. Ciênc. Esporte, vol. 34, no.1, pp. 111-126, January 2012.

[35] S. M. S. Iunes and G. L. Santos, "Engagements and disengagements between informatics and mathematics education," Ciência \& Educação (Bauru), vol.19, no. 2, pp. 293-305, 2013.

[36] J. Bidarra, C. Boscarioli, and S. M. Peres, "Xlupa software - A screen magnifier to aid in educating students with low vision" Revista Brasileira de Educação Especial, vol. 17, no. 1, pp. 151-172, January 2011.

[37] F. C. S. Galli, "Discourse about reading in contemporaneity: Between paper-text and screen-text," Trabalhos em Linguística Aplicada, vol. 51, no. 1, pp. 175-192, January 2012

[38] R. L. M. D. Silva, S. S. D. C. Silva, F. A. R. Pontes, A. I. A. D. Oliveira, and D. Deliberato, "The effects of alternative communication in the interactions between a teacher and a nonspeaking student with cerebral palsy," Revista Brasileira de Educação Especial, vol. 19, no. 1, pp. 25-42, January 2013

[39] C. B. Zandavalli and D. M. Pedrosa, "Establishment and implementation of Proinfo in the municipality of Bataguassu, in Mato Grosso do Sul: The view of education professionals," Revista Brasileira de Estudos Pedagógicos, vol. 95, no. 240, pp. 385-413, May 2014

[40] H. H. O. D. M. Couto, "Novice teachers in the context of practice and the information and communication technologies (ICT)," Educação \& Sociedade, vol. 35, no. 126, pp. 257-272, January 2014.

[41] F. S. Saito and P. N. D. S. Ribeiro, "Digital (multi) literacy (ies) and positioning theory: analysis of discursive practices of teachers involved with information and communication technologies in the public education," Revista Brasileira de Linguística Aplicada, vol. 13 no. 1, pp. 37-66, January 2013

[42] L. R. Bardy, M. C. P. I. Hayashi, E. T. M. Schlünzen, and M. O. Seabra Júnior, "Objects for Learning as educational resources in inclusive contexts: support for distance teacher education," Revista Brasileira de Educação Especial, vol. 19, no. 2, pp. 273-288, April 2013

[43] A. S. D. Bona and M. V. D. A. Basso, "Mathematics Portfolio: an instrument for analyzing the learning process," Bolema: Boletim de Educação Matemática, vol. 27, no. 46, pp. 399-416, August 2013.

[44] P. A. Pinheiro, "Text production practices on MSN: Redifining collaborative writing," Revista Brasileira de Linguística Aplicada, vol. 10, no. 1, pp. 113-134, 2010

[45] N. P. G. de Azevedo, F. M. B. Júnior, and E. P. Daróz, “O professor e as novas tecnologias na perspectiva da análise do discurso:(des) encontros em sala de aula," Linguagem em (Dis)curso, vol. 14, no. 1 , pp. 15-27, January 2014.

[46] $26^{\circ}$ pesquisa anual do uso de TI. (2015). [Online]. Available http://eaesp.fgvsp.br/sites/eaesp.fgvsp.br/files/arquivos/pesti-gvcia20 15ppt.pdf 
[47] 68 milhões usam a internet no Brasil. (2015). [Online]. Available: http://www.nielsen.com/br/pt/press-room/2015/68-milhoes-usam-a-in ternet-pelo-smartphone-no-Brasil.html

[48] The Internacional Development Research Center (IDRC). (August 2014). La Evolución de la Sociedad de la Información en América Latina - 2000-2025. Informe de investigación del proyecto "25 Años," 2012. [Online]. Available: http://www.info25.org/es

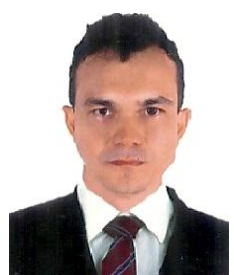

Eurival Alves de Souza Eurival Alves de Souza was born in the city of Itacajá, Tocantins, Brazil, on February 26, 1968. He got his degree in education, in 2002, at Unitins, in the city of Palmas, state of Tocantins, Brazil. He got his second degree in teaching informatics at the Federal University of Tocantins (Universidade Federal do Tocantins), PARFOR program, Palmas, Brazil.

He has been a teacher for 21 years. He is a public servant at the Municipa Education Secretary (Secretaria Municipal de Educação) of Colinas do Tocantins, Brazil.

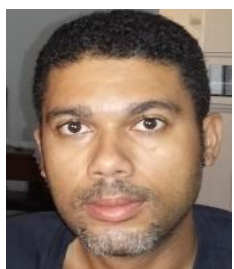

Leandro Guimarães Garcia was born in the state of Goiás (Brazil) in 1978. He has a bachelor's degree in biomedicine from The Federal University of São Paulo (Brazil) and finished his doctorate in cell and molecular biology in the University of Brasilia (Brazil) in 2006

He worked as a teacher and the coordinator of the biomedicine undergraduate course of the Faculty of
Higher Education of the United Amazon (FESAR) and currently is an associate professor at the Federal University of Tocantins. In this university he works developing ELVs for embryology, parasitology, and human anatomy teaching. Currently he also works with research and development in the field of health computing.

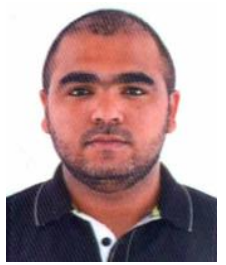

Janio Carlos Nascimento Silva was born in the city of Imperatriz, Maranhão, Brazil, on February 1, 1990. He graduated in computer science, in 2012, by Federal University of Tocantins, Palmas, Tocantins, Brazil. He was a master's student by the post-graduate program in computer modeling of systems in the same institution. He works in Federal Institute of Education, Science and Technology of Tocantins as professor of technical and technological education in the city of Porto Nacional, Tocantins, Brazil.

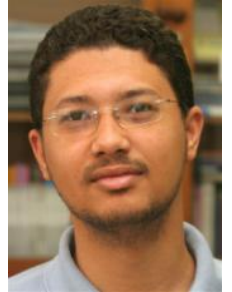

Leonardo Guimarães Garcia was born in Anapolis, Goias, Brazil. He's got his degree in engineering in 1996 (University of Sao Carlos, Sao Paulo, Brazil), his master's degree in mechanical engineering in 1999 (University of Sao Paulo, Brazil) and the $\mathrm{PhD}$ in engineering in 2005 (University of Sao Carlos, Brazil). His professional activities are directed to the area of Information and its use in decision process. $\mathrm{He}$ is a professor at the University of Sao Paulo since 2010 